\title{
La ilustración de los cuentos de Perrault: tantas Caperucitas como lobos
}

\author{
Verónica Murillo Chinchilla \\ Escuela de Lenguas Modernas \\ Universidad de Costa Rica \\ Escuela de Literatura y Ciencias del Lenguaje \\ Universidad Nacional
}

\begin{abstract}
Resumen
El presente artículo propone un recorrido cronológico por las diferentes ilustraciones del cuento de Charles Perrault Caperucita Roja, así como de su posterior versión modificada por los hermanos Grimm. Mediante el estudio de dibujos y grabados desde la primera edición en 1695 hasta la de 1965, se analizan las diferentes implicaciones estéticas y culturales identificables en las distintas propuestas artísticas.
\end{abstract}

Palabras clave: Caperucita Roja, Charles Perrault, hermanos Grimm, cuentos para niños, libro-álbum, literatura francesa del siglo XVII

\section{Résumé}

Cet article propose un parcours chronologique des diverses illustrations du conte de Charles Perrault : Le Petit Chaperon rouge, ainsi que de sa version modifiée créée par les frères Grimm. Des dessins et gravures depuis la première édition de 1695 et jusqu'en 1965, sont étudiés pour proposer une analyse des implications esthétiques et culturelles repérables dans les différentes propositions artistiques.

Mots clé : Le Petit Chaperon rouge, Charles Perrault, frères Grimm, contes pour enfants, livre-album, littérature française du XVIIe siècle

\begin{abstract}
This article presents a chronological journey through the different illustrations of Charles Perrault's tale Red Riding Hood, as well as its subsequent version modified by Grimm brothers. The study of drawings and engravings from the first edition in 1695 until 1965 suggests an analysis of the aesthetic and cultural implications found in different artistic proposals.
\end{abstract}

Key words: Red Riding Hood, Charles Perrault, brothers Grimm, children's tales, book-album, seventeenth century French literature 


\section{Introducción}

$\mathrm{D}$ urante más de tres siglos, las ilustraciones de los cuentos de Perrault han mantenido el interés de los artistas ilustradores y del mercado editorial. Por otra parte, reconocidos artistas se han ocupado de plasmar su visión de los personajes clásicos, de tal forma que puede constituir una iconografía rica, variada y representativa de una larga línea de tiempo.

Además, cada cuento posee múltiples representaciones, por lo que la selección está determinada por el hecho de que se trata de un cuento que, efectivamente, fue imaginado para niños. Independientemente de las interpretaciones de la cuales ha sido objeto, Caperucita Roja continúa siendo parte de las historias con las que los niños pueden identificarse fácilmente, por corta que sea su edad. La heroína que se resiste a crecer, se asegura así de seducir permanentemente a los artistas, quienes han brindado a través de los años multiplicidad de Caperucitas y de lobos.

Al proponer un estudio de las ilustraciones de un cuento de la tradición popular, los referentes teóricos deben combinar las teorías sobre el cuento junto con estudios acerca de la importancia de las ilustraciones en los libros infantiles. Por ello, los estudios de los estructuralistas siguen vigentes para comprender la arquitectura interna de un cuento.

Así, las propuestas teóricas presentes en la Morfología del cuento de Vladimir Propp (1972) o la aplicación de los postulados de la Introducción al análisis estructural del relato de Roland Barthes (1972), o la influencia de la Lógica de los posibles narrativos de Claude Bremond (1972), se convierten en un marco referencial adecuado y pertinente para adentrarse en el estudio de Caperucita roja de Charles Perrault, sin olvidar tampoco la versión posterior de los hermanos Grimm.

De la misma forma, es necesario recurrir a estudios como los de Louis Marin (1990) y Ségolène Le Men (1992) acerca de las ediciones de los Cuentos de Mamá Oca para valorar la importancia de la simbiosis entre los cuentos y las ilustraciones, para el imaginario colectivo. Otras contribuciones son también necesarias, como el estudio de Fanuel Hanan Díaz (2007) sobre el libro álbum como un género en construcción, o las relaciones entre imagen y texto en los libros ilustrados infantiles de Cecilia Bajour y Marcela Carranza (2008).

A partir de lo anterior se evidencia que la aproximación interpretativa conveniente para este estudio se sustenta en la aplicación de un marco teórico ecléctico, el cual permite abordar el material disponible para analizar, tanto en la especificidad de cada ilustración, como en las interrelaciones establecidas entre todas ellas alrededor de una línea temporal. De tal forma, la aplicación de dichos referentes se desarrolla a continuación.

\section{La iconografía como respuesta necesaria}

Cuando Charles Perrault, en plena época del Clasicismo francés (siglo XVII), decidió escribir sus cuentos, estaba consciente de que retomaba una larga 
tradición oral, transmitida de generación en generación. Los cuentos de mi madre la Oca, el manuscrito de 1695 que se le atribuye, estaba destinado a la sobrina de Louis XIV, Elisabeth Charlotte de Orléans.

Aunque este manuscrito no está firmado por Perrault, actualmente, no existen dudas acerca de su autoría. Ahora bien, siguiendo los usos de la época, el prefacio del autor se convierte en un documento valioso para comprender la forma en que él mismo valora y estima necesaria la publicación de su obra.

En el caso de Perrault, la intención de retomar la tradición de los ancestros para fomentar los valores morales se convierte en el eje en torno al cual giran las historias que componen la antología.

Dans les contes que nos aïeux ont inventés pour leurs enfants, ils ont toujours eu un très grand soin que leurs contes renfermassent une moralité louable et instructive. Partout la vertu y est récompensée, et partout le vice y est puni. Ils tendent tous à faire voir l'avantage qu'il ya d'être honnête, patient, avisé, laborieux, obéissant, et le mal arrive à ceux qui ne le sont pas. (Perrault, $2000: 17){ }^{1}$

De tal forma, queda claro que cada uno de los Cuentos de Mamá Oca, conlleva una lección moral destinada a mostrar el recto camino y hacer temer el castigo por no seguirlo.

Por otra parte, la acogida y popularidad de las historias en la pluma de Perrault, pronto evidenciaron la necesidad de crear sus propias representaciones iconográficas. Los lectores querían verlas desde lo que hasta entonces debían imaginar: la maldad del lobo y de Barbazul, la astucia del Gato con botas, la belleza de Cenicienta, por ejemplo. Así, desde la primera edición impresa por Barbin en 1697, las viñetas acompañan las historias y establecen una especie de complemento necesario para la significación del cuento.

Entonces, ante una tradición tan arraigada en el imaginario colectivo, se abre la posibilidad de concentrarse en la forma en que dichas representaciones icónicas han ido evolucionando. Se trata de una tradición de más de tres siglos que ha conocido los avances de la técnica así como las variaciones del arte y que proveerá, sin duda, un interesante recorrido cronológico.

Por ende, el planteamiento de Le Men acerca de las perspectivas desde las cuales pueden ser consideradas las ilustraciones constituye el sustento del interés de la presente reflexión:

As a series of pictures, illustrations may be considered from two perspectives: one may study the sequence of images in a single Edition; or one may investigate iconographic transformations in successive versions of the same episode. [...] This last approach reveals changes in the reading and intended reception of the text. In fact, the ideal method is to combine two, using both the syntagmatic and the paradigmatic axes in order to detect illustrative archetypes and trace their derivations as stereotypes. (Le Men, 1992: 18) ${ }^{2}$ 
Así, se evidencia que el estudio de las ilustraciones de una narración puede convertirse en un precioso recurso para valorar la recepción del texto a través del tiempo. En virtud de ello y según Le Men (1992), el procedimiento ideal combina el análisis de las diferentes imágenes en una misma edición con el estudio comparativo de las transformaciones iconográficas del mismo episodio en diferentes versiones. Todo ello con el objetivo de acercarse a los arquetipos y a través de estos identificar la huella de los estereotipos.

\section{El nacimiento del prototipo}

De este modo, desde el manuscrito de 1695 y la edición Barbin de 1697 se presenta una serie de ilustraciones de Caperucita roja, de la cual nos ocuparemos en las páginas subsiguientes. Cabe mencionar que el patrimonio iconográfico disponible de los siglos XVII y XVIII retrata, básicamente, dos tipos de ilustración: Caperucita sola en el bosque o Caperucita con el lobo en casa de su abuela, por lo que el estudio se ocupará de los dos tipos en forma separada. Además, un tercer tipo de ilustración presente en ediciones más recientes muestra el encuentro de la niña y el lobo en el bosque; este también será reseñado por aparte, junto con las tendencias que marcaron el paso al siglo XX.

Figura 1

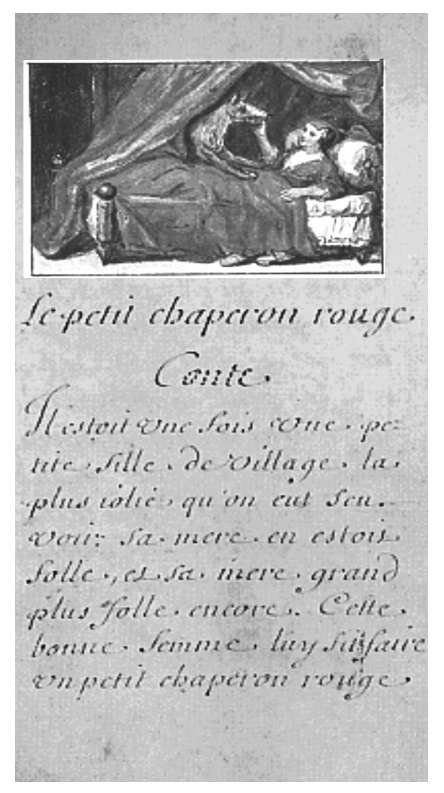

Manuscrito, 1695

Con base en lo anterior, el primer rasgo que destaca en las imágenes más antiguas es que se concentran en el momento más dramático del relato: Caperucita será devorada por el lobo. No obstante, la fuerza de la tradición clasicista impera también en los preceptos que rigen lo que es o no correcto representar. Tal 
y como Lessing (1960) planteaba: el efecto ambiente está mejor acabado cuando no se representa el clímax, sino el instante previo, dejando libre la imaginación sobre lo que vendrá. Por lo tanto, Perrault y sus ilustradores seguían las normas de la bienséance (decoro), tan arraigadas en la tradición artística francesa.

Figura 2

Edición Barbin, 1697

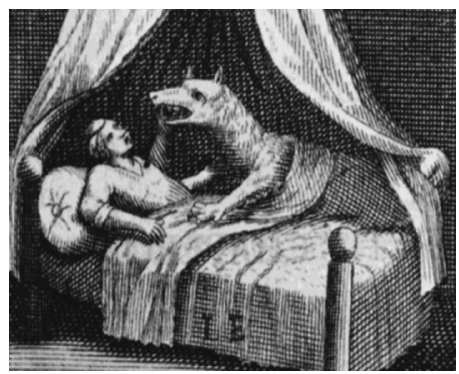

Por su parte, una edición holandesa del siglo XVIII parece mostrar una primera evolución en ese sentido, puesto que transgrede la representación del momento previo al clímax para evidenciar el paso a la acción, como muestra la figura 3. El dramatismo pasa al desagrado y a la concretización de las consecuencias de ser imprudente; el lector no tiene que "imaginar" el castigo, lo está viendo.

Figura 3

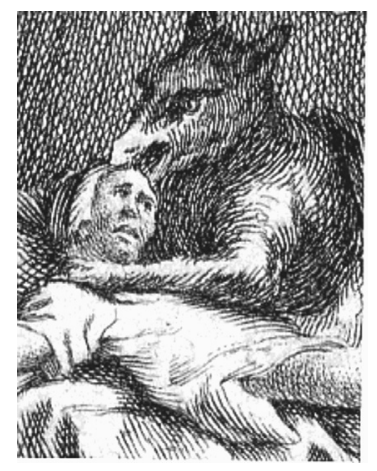

Ilustración de Simon Fokke siguiendo diseños de Jacques de Sève, La Haya, 1742

\section{Consolidación iconográfica del momento central}

De igual manera, la tradición iconográfica permanece más bien pasiva a lo largo del siglo XVIII, para volverse de nuevo fructífera durante el siglo XIX. Las razones son fácilmente explicables; por un lado, los avances del mercado editorial jugaron un rol decisivo en la popularización de libros ilustrados, y la invención y el mejoramiento de técnicas como grabado y litografía proveyeron terreno fértil para revisitar los textos clásicos y dotarlos de múltiples manifestaciones visuales. Por otro lado, la posibilidad de recibir instrucción y de adquirir libros 
había variado definitivamente desde el siglo XVII, lo que explica que fueran rentables, desde el punto de vista comercial, los tirajes de ediciones ilustradas. De esta época, incluso, puede encontrarse un lienzo con una representación de Caperucita, pintado por Fleury François Richard y, actualmente, exhibido en el Museo del Louvre.

Por otra parte, en lo referente a las ilustraciones impresas, su número y variedad se amplía interesantemente después de 1840. El interés de ilustradores y editores trasciende Francia y Holanda, en tanto nuevas variaciones aparecen casi simultáneamente.

De este modo, las ilustraciones cuentan con mayor riqueza de detalles, al tiempo que revelan usos de la época. Así, la figura 4 muestra una Caperucita vestida a la moda burguesa del siglo XIX francés; está desprovista de su capa y lleva sombrero a la usanza de las "niñas bien". También, pueden verse las ropas del lobo convertido en abuela, así como el lecho y los artefactos en la mesa de cabecera. Estos dan muestras de cierto nivel de vida y holgura económica.

Por su parte, la litografía de Eugène Feyen muestra la ambigüedad de la escena en que el Lobo quiere convencer a Caperucita de entrar en la cama.

Figura 4

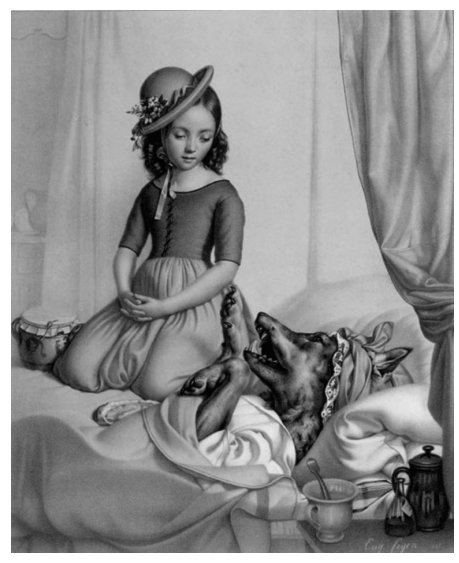

Eugène Feyen, litografía, 1846

Con base en esto, recuérdese que la versión del cuento de Perrault está desprovista de un final feliz para Caperucita, pues el lobo, efectivamente, se la come. De tal forma que esta ilustración representa un momento decisivo: la muchachita (no tan niña) que está de rodillas y completamente vestida, pareciera dudar de acceder a las peticiones de la falsa abuela. Sin embargo, la cabeza inclinada, los ojos bajos y las manos cruzadas sobre el regazo son signos inequívocos de la moralidad de la época, la cual pretendía de la mujer una actitud recatada y sumisa.

La siguiente figura cuenta con la particularidad de haber sido elaborada durante la década de 1860 y su mayor mérito es mostrar el grado de perfección y detalle conseguido con las innovaciones en las técnicas de impresión. Es necesario mencionar, en primera instancia, que la figura 5 pertenece a la célebre edición de los cuentos de Perrault ilustrada por Gustave Doré. 
Figura 5

Gustave Doré, 1862, grabado en madera

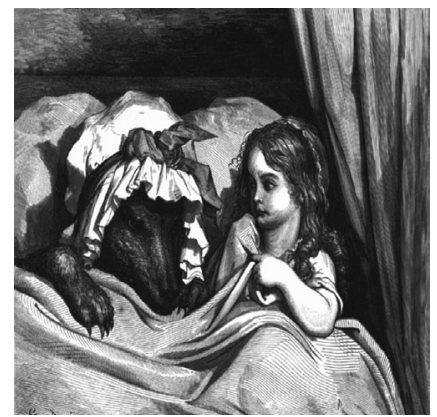

Consecuentemente, el grabado de Doré se concentra en el momento crucial en que Caperucita se debate entre la repulsión ante la abuela, que no reconoce, y la curiosidad hacia el nuevo aspecto físico de su ser querido: tal circunstancia se evidencia en la mirada fija de la niña, aunada a una impresión de distanciamiento a pesar de la cercanía física entre los dos personajes. También, el lobo, por su parte, ya puede presentir que está listo para el ataque, tal y como lo muestran sus garras y la mirada codiciosa que dirige a la niña. En este caso, conviene destacar la escogencia de Doré de la imagen de su heroína, al mostrarla como una niña todavía, lo que la relaciona más con la ingenuidad, así como con la imprudencia. Obsérvese, finalmente, la ausencia de detalles secundarios que distraigan la atención del espectador.

Así mismo, a fines del siglo XIX, conviene destacar la ilustración de Carl Offterdinger, la cual muestra el encuentro entre el Lobo y Caperucita en la habitación de la abuela. En primera instancia, dicha imagen muestra que la mirada del lobo dista mucho de ser feroz, parece más bien compungida; el engaño es más acabado, en el sentido de que la mirada tiene más parecido con la que podría tener la abuela. A esto se suma el hecho de que el lobo oculta sus fauces y garras bajo las sábanas. Es decir, el lobo de Offterdinger realmente trata de suplantar a la abuela. Además, pueden observarse detalles de la decoración: la abuela es instruida y sabe leer, así lo indican sus anteojos y los libros en la cabecera y en la repisa del fondo. El libro junto al lecho bien podría ser una Biblia.

Figura 6

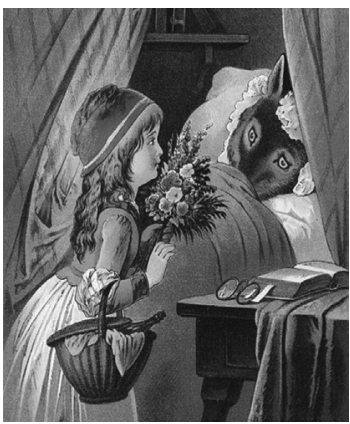




\section{Nuevas posibilidades representativas}

A medida que avanza el siglo XIX se presentan dos modificaciones esenciales en relación con las ilustraciones de este cuento. La primera es que se populariza, definitivamente, la versión de Caperucita de los hermanos Grimm, en la cual Caperucita y su abuela son rescatadas por un cazador, lo que transforma la historia en un cuento con final feliz. La segunda es que los avances en las técnicas de impresión permiten a editores e ilustradores interesarse en nuevas escenas "ilustrables" de los cuentos.

De esta forma, no solamente el momento en que el lobo devora a Caperucita va a ser objeto de interés, sino también el encuentro con el lobo en el bosque, la muerte de la abuela y hasta el rescate por parte del cazador ocupan una nueva serie de ilustraciones.

De nuevo, Gustave Doré marca la pauta al haber realizado dos grabados más para el cuento: el primero muestra el encuentro entre el lobo y la niña; el segundo representa el momento en que la abuela es devorada.

La figura 7 muestra la primera escena de la edición Hetzel, ilustrada por Doré. Los dos personajes principales del cuento se encuentran en el bosque, Caperucita no lleva una capa roja sino un delantal y una boina sobre su cabeza. Los alimentos que lleva para su abuela están expuestos a la vista del espectador. La luz se centra sobre ella, creando así diferentes niveles de suspenso en la percepción de las imágenes. La expresión del rostro de la niña es más bien ambigua, pues no se percibe temor en su mirada, está mirando de igual a igual a un animal más grande (y desde luego más poderoso que ella) y su mano derecha parece señalar su destino.

Figura 7

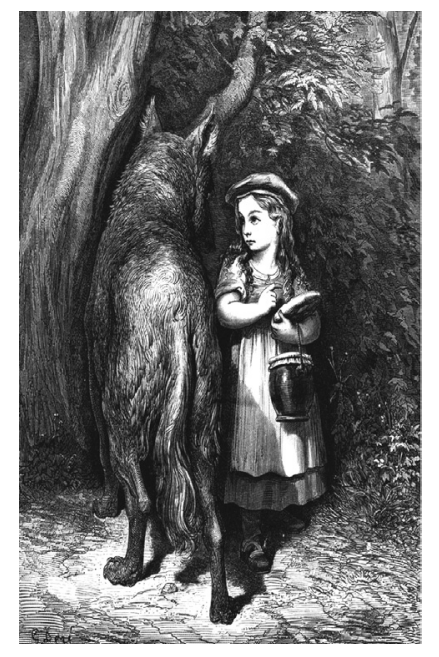

Gustave Doré, 1862

Un segundo plano de atención es ocupado por el lobo; detalle esencial, la cara del animal, personificación de la maldad, permanece oculta al espectador, quien tiene que imaginar la expresión engañosa con la que el animal obtiene la 
información deseada. Doré retoma el imaginario colectivo en el sentido de que el enemigo cobarde ataca por la espalda y nunca da la cara. No obstante, es evidente el poderío físico del lobo.

Un tercer plano de atención se refiere al ambiente que rodea a los personajes, una arquitectura vegetal abigarrada y poderosa, casi como una naturaleza caníbal dispuesta para tragarse a sus personajes en el momento en que salgan del claro. La representación de ese entorno natural exuberante es una de las características artísticas de Doré.

Figura 8

Edición holandesa, 1856

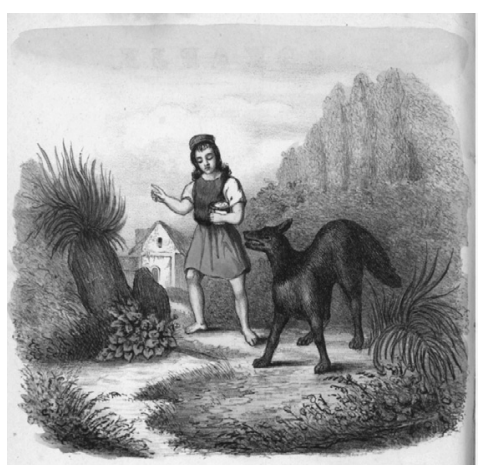

Por su parte, las ediciones holandesas del cuento de Caperucita muestran un lobo menos misterioso que el de Gustave Doré. Tal y como puede verse en la figura 8, en la que además llama la atención la vestimenta sencilla de la protagonista. Los dos personajes están situados en un paisaje muy diferente del bosque tenebroso o grandioso de los ilustradores franceses de la misma época; en este caso, se presenta una atmósfera mucho más despejada. Sin embargo, Caperucita mantiene el gesto de señalar hacia dónde se dirige.

En 1868 puede encontrase otra representación pictórica de Caperucita, lo que muestra la coexistencia del mercado editorial con el interés de los pintores por encontrar sus motivos de inspiración en motivos universales, como los cuentos.

El interés ilustrativo se mantiene, desde luego, al entrar en el siglo XX. Pero las variaciones que acompañan la evolución temporal revelan modificaciones estéticas importantes, atribuibles a dos situaciones por lo menos. La literatura había evolucionado en la segunda mitad del siglo hacia el Realismo y el Naturalismo. Por ende, la figura 9 parece adscribirse a los nuevos intereses al presentarnos un lobo que no había sido ilustrado así, hasta entonces.

Puede observarse, en primera instancia, la diferencia de tamaño entre la niña y el lobo, la cual marca la jerarquía entre los personajes en ese momento narrativo. Caperucita representa la imagen de ingenuidad tan desaconsejada por Perrault. En tanto que los árboles presentan un aspecto más bien siniestro, debido a la monumentalidad de sus troncos y los salientes que parecieran brazos listos para entrar en acción. 
Figura 9

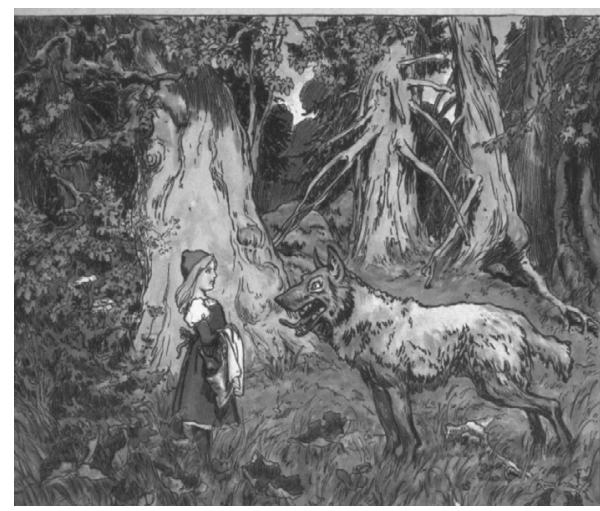

Van Holkema y Warendof, 1905

Pero ante todo, es notorio el personaje del lobo, provisto de una mirada que no deja lugar a dudas sobre el objeto del deseo sobre quien se dirigen sus acciones. Sus fauces abiertas no evidencian, precisamente, una conversación amigable, sino malintencionada. Esto también se evidencia en su postura, con el cuerpo fuertemente inclinado hacia adelante, listo para apropiarse de su presa. El lector tiene la sensación de que Caperucita va a ser devorada en ese mismo instante.

Otra imagen holandesa, esta vez de 1907, muestra el encuentro entre los dos personajes, pero aquí el lobo está exento de la crueldad con que fue representado en la figura anterior. El rasgo particular de la imagen es que invierte los papeles de Doré. En este caso, es Caperucita quien oculta su rostro, en tanto que el lobo puede verse con expresión casi humana; su mirada persuasiva haría pensar al lector que se trata de un lobo inofensivo.

\section{Figura 10}

L. Meggendorfer, 1907

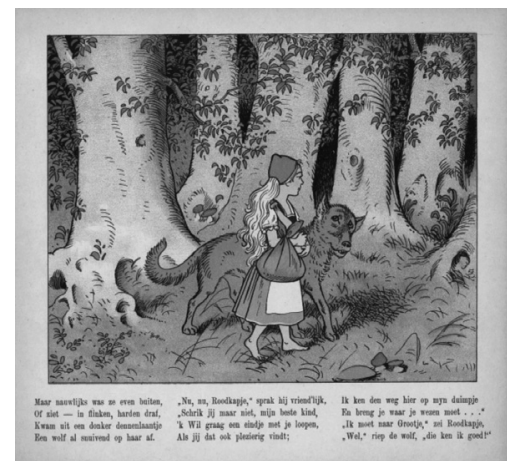

El bosque también está dibujado con árboles enormes, pero las coníferas son reemplazadas y no tiene aire siniestro. Además, la apariencia física de Caperucita es más la de una adolescente que la de una niña; el detalle que atrae la atención es que la vestimenta de la protagonista corresponde a la de una campesina holandesa de la época. 
Representaciones como la de figura 10 tomarán fuerza más adelante. Sin embargo, los cambios son lentos y la imagen de cuentos para niños, acompañados de ilustraciones más o menos naïves, sigue estando fuertemente marcada. Así lo muestra el ilustrador belga de la figura 11, en la cual realza el candor y la frescura de la infancia mediante imágenes altamente coloridas y sencillas.

\section{Figura 11}

Edgar Tijtgat, 1921

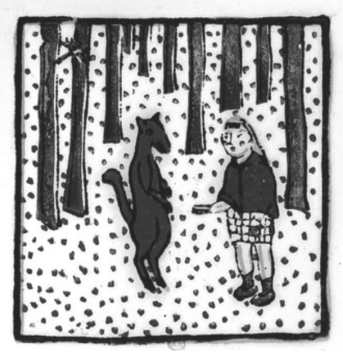

Es decir, las modificaciones estéticas también van en el sentido de asimilar las ilustraciones a los dibujos infantiles y se apartan de apariencias psicológicamente perturbadoras. Las imágenes son visualmente placenteras y no permiten intuir la magnitud de los sucesos que serán narrados. Los personajes son presentados de igual a igual, casi como amigos. Esta intención aplica igualmente en la siguiente ilustración:

\section{Figura 12}

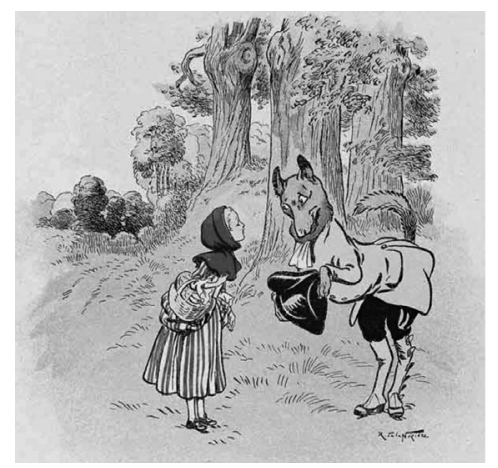

René de la Nézière, 1921

La edición en la que aparece esta ilustración (Les Contes de Perrault, Tours, Mame) estaba destinada a niños pequeños, por lo que el ilustrador decide prescindir de los detalles violentos y los posibles contenidos sexuales de otras ilustraciones. Como puede verse, el encuentro entre Caperucita y el lobo está marcado por la cortesía, la mirada de este no tiene ninguna de las connotaciones codiciosas o perversas con que aparece en otras figuras. Los dos personajes están situados a una distancia que marca el respeto que se profesan; pero, al mismo tiempo, sus posturas están inclinadas hacia delante, con lo cual manifiestan mutuo interés. Esta disposición recuerda el ritual japonés del saludo. 
Además de la expresión seria de Caperucita, cabe destacar la vestimenta de los personajes, al mejor estilo de un caballero y una dama. El lobo pierde su apariencia animal, está erguido y lleva su traje con completa seguridad, así como sostiene el sombrero entre sus garras, que apenas lo parecen.

Estas representaciones coexisten con miradas más sombrías, tal y como puede verse en la figura siguiente (13), en donde el lobo vuelve a erigirse en presencia dominante y amenazante, de la cual Caperucita no podrá escapar. La forma en que descorre la cortina, con su cuerpo inclinado y una expresión expectante, no refleja curiosidad, sino más bien aprehensión. La protagonista no está representada como una niña, sino como una muchacha. Por lo tanto, su fisionomía ha evolucionado en esta ilustración desde la apariencia infantil hasta el aspecto marcadamente acusado de una mujer joven. Estos detalles revisten una importancia particular cuando se piensa en el aspecto moralizante que Charles Perrault había querido dar a sus cuentos.

\section{Figura 13}

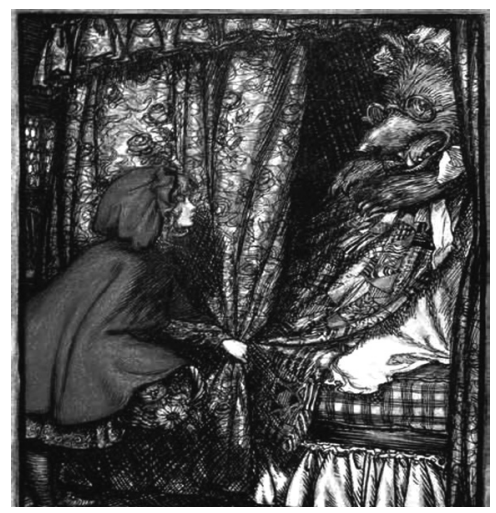

Arthur Rackham, 1922

Entonces, los personajes pasan a ser alegóricos y la maldad del lobo es la maldad del hombre que amenaza con despojar de su virtud a toda mujer imprudente que no guarde la debida discreción. El autor lo anunciaba explícitamente en las moralejas que acompañaban la primera edición de sus cuentos:

Je dis loup, car tous les loups

Ne sont pas de la même sorte ;

Il en est d'une humeur accorte

Sans bruit, sans fiel et sans courroux

Mais hélas! qui ne sait que ces loups doucereux,

[...] De tous les loups sont les plus dangereux. (Perrault, $2000: 77)^{3}$

Otro de los cambios que merece atención durante el siglo XIX y XX tiene que ver con las figuras representadas por los artistas. Las ilustraciones dejan de concentrarse únicamente en el lobo y Caperucita, para dar protagonismo a esta última, en forma aislada. 


\section{Las diferentes caras de Caperucita}

Estas interpretaciones del cuento permitirán explorar la forma en que la heroína es percibida como ente individual. Además, permiten visualizar concepciones estéticas de la imagen femenina que van desde la inocencia infantil hasta una incipiente mujer que se inicia en los misterios de la vida sexual.

Cabe anotar que la presentación de las figuras respeta, como hasta ahora, el orden cronológico. La figura 14 corresponde a una edición holandesa de mediados del siglo XIX, en la cual puede apreciarse una Caperucita púber con actitudes femeninas que remiten al aspecto erótico del encuentro entre los dos personajes. Puede verse a la muchacha junto a lo que parece ser un tocador provisto de un espejo, los gestos de la ilustración indican claramente que se está desvistiendo.

\section{Figura 14}

Edición holandesa, 1843

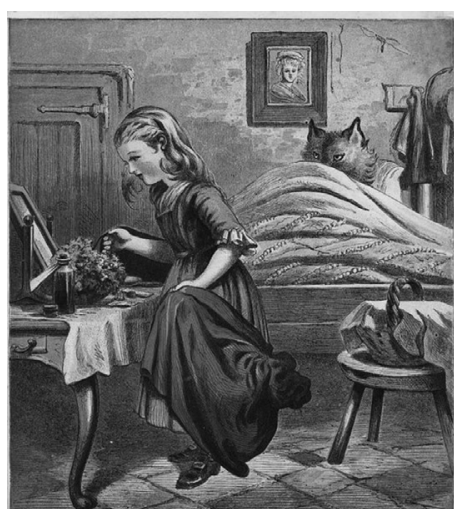

La composición de la ilustración muestra variados elementos, la escena se produce en un recinto cerrado (íntimo), la disposición de la atmósfera excluye la presencia de salidas, a la protagonista le será imposible escapar. Además, al observar el lenguaje corporal de los personajes, puede verse el lobo al acecho, semioculto tras las sábanas, pero listo para lanzarse tras su presa, el animal está representado en lo más puro de su carácter depredador: tiene la paciencia necesaria para esperar el mejor momento de atacar.

La muchacha, de trazos finos y delicados, mantiene la mirada baja, justo como en la ilustración de la figura 4, lo que recuerda el ideal femenino de la época, a saber, la señorita recatada y sumisa. Otro detalle interesante es el hecho de incluir la presencia de la abuela mediante un retrato que cuelga de la pared, en la cabecera de la cama, ¿es este retrato una referencia hacia la omnipresencia de la autoridad moral que la muchacha está a punto de transgredir? Quizá eso explique la postura que da la espalda al lobo, pero también a la imagen de la abuela. El momento es decisivo, la muchacha está entrando en un punto de no retorno, pues su vida no volverá a ser la misma. De tal forma, la ilustración enfatiza el momento previo al clímax, el cual supone una fuerte carga erótica en la recepción por parte del espectador. 
El efecto es muy diferente, por ejemplo, del representado en la siguiente figura, perteneciente a una edición inglesa. En este caso, Caperucita recupera su apariencia puramente infantil, deviene incluso angelical, la expresión de inocencia no puede estar mejor representada mientas espera pacientemente al otro lado de la puerta. Es su vestidura la que nos indica el personaje representado, pues efectivamente lleva puesta la capa roja más clásicamente asociada a su nombre. El resto de los elementos de la composición no son particularmente reveladores de los sucesos narrados en el cuento. No son visibles los comestibles que lleva a su abuela y se trata de la representación de un ambiente externo, fácilmente asociable con cualquier entorno rural.

\section{Figura 15}

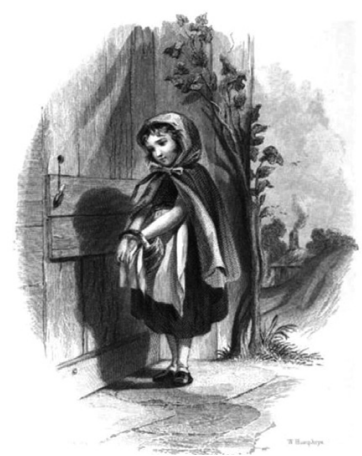

Frances Sargent Osgood, 1850

Las dos ilustraciones inglesas del siglo XIX de que se dispone en este estudio comparten el rasgo de mostrar una Caperucita realmente infantil, desprovista de apariencia o actitudes que la asocien con un posible despertar sexual, como es sugerido en otras ilustraciones. La figura 16 representa uno de los acabados mejor logrados de pintura clásica, cuyo autor George Frederic Watts fue un pintor victoriano fuertemente influenciado por la obra de Miguel Ángel y el Renacimiento italiano, no en vano su Caperucita recuerda a los ángeles de Rafael de Sanzio.

\section{Figura 16}

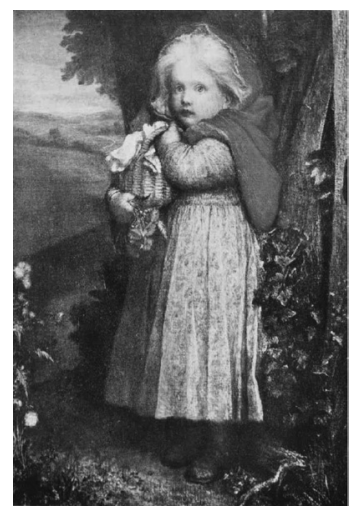


Llama la atención la riqueza en el uso del color y el juego entre luces y sombras. La protagonista comparte los rasgos robustos de las ilustraciones de Doré y su fisionomía es típicamente inglesa: los ojos muy azules, las mejillas sonrosadas y la boca roja. Además, los detalles de su vestimenta son muy elaborados, se prescinde del uso de coloración uniforme para recurrir a tonalidades y figuras que representan texturas. La niña sostiene la canasta con el encargo para su abuela, con una actitud típicamente infantil de egoísmo, como si temiera que alguien se la arrebatara.

\section{Figura 17}

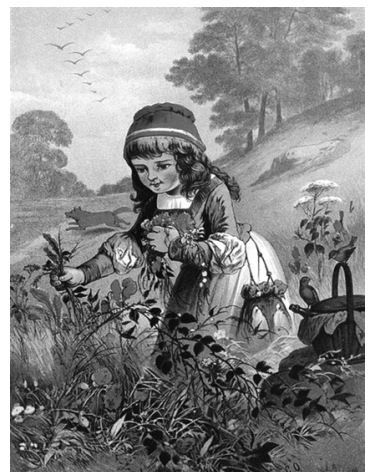

Carl Offterdinger, finales del siglo XIX

También el alemán Carl Offterdinger propone una Caperucita infantil, como puede verse en la figura 17. En la ilustración, la protagonista no se encuentra en el bosque, sino más bien en un prado; el paisaje es idílico con flores multicolores y pájaros cerca de la niña y en el cielo. Sólo un detalle perturba la escena, el lobo en franca carrera cerca del punto de fuga de la ilustración; sin embargo, de no detenerse en observar la ilustración, la circunstancia podría pasarse por alto. En efecto, la atención está concentrada en la niña que recoge flores, no lleva una capa roja, solamente un sombrero de ese color y está vestida elegantemente como lo muestra el bolsito que cuelga de su hombro. Toda su actitud es de ensimismamiento en la tarea placentera que la ocupa.

\section{Figura 18}

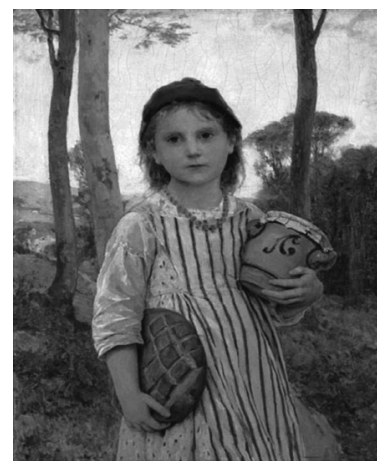


A su vez, la ilustración de Caperucita por parte del suizo Albert Anker destaca por la pureza de los rasgos de la protagonista. Ella está vestida con sencillez y apenas un pequeño sombrerito rojo nos recuerda que se trata de Caperucita; sin embargo, los comestibles que lleva en sus manos confirman inequívocamente el personaje del cuento. Reviste importancia el uso de un delantal con rayas azules y un detalle de coquetería: un collar de cuentas azules.

Ahora bien, interés aparte merece la mirada de la niña y su expresión indefinible, perdida como el recodo del camino en donde está representada. ¿Está triste? ¿Temerosa? ¿Tiene una ensoñación?, parece imposible saberlo, excepto que la mirada indica un espíritu que se aleja de la representación, casi tan enigmática como la Gioconda de Da Vinci.

Ese tipo de representaciones contrasta fuertemente con aquellas claramente destinadas a públicos infantiles, las cuales buscan atraer mediante el colorido y la simplicidad de formas, sin juegos de luces y sombras, o expresiones difíciles de descifrar.

\section{Figura 19}

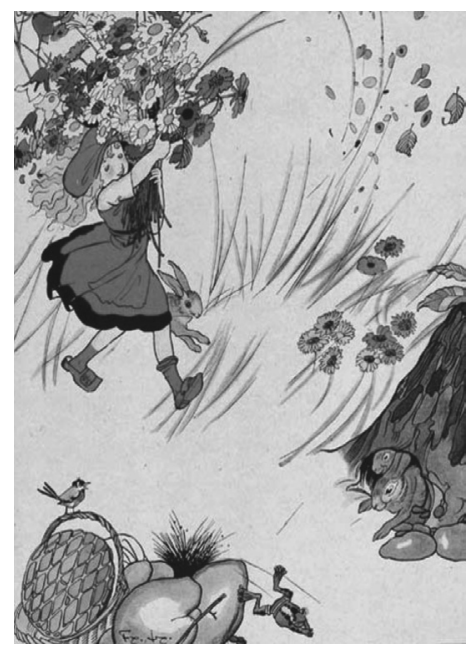

Félix Lorioux, 1920

Esta ilustración de 1920 retoma el momento en que Caperucita, distraída, se entretiene recolectando flores, antes de visitar a su abuela. La visión es resueltamente infantil donde toda escena que pueda resultar chocante es evitada. Se trata de una niña feliz y despreocupada. El cuadro está complementado por otros animales como pájaros, conejos y ranas que comparten el momento placentero en una imagen cargada de movimiento.

También, existe una ilustración anónima en una edición inglesa de los años 20 que no quisiéramos soslayar, puesto que, pese a ser contemporánea de la ilustración anterior, retoma las líneas inspiradoras venidas desde el siglo XVII. Es decir, en estas se privilegia el sentimiento perturbador en el lector, sea porque representan un ambiente siniestro, sea porque sugieren una Caperucita a las puertas del despertar sexual. 
Así puede verse en la figura 20, en la cual el bosque tiene más bien un aspecto fantasmagórico, sin formas definidas en los árboles o la vegetación. El personaje principal lleva puesta la clásica capa roja que lo define, pero lleva en un cesto los comestibles para su abuela. Al concentrarse la mirada en el aspecto físico de Caperucita, puede verse que no se trata de una niña, sino de una adolescente bella y fresca, quien tiene la mirada baja, abstraída en sí misma.

\section{Figura 20}

Ilustración inglesa, década de 1920

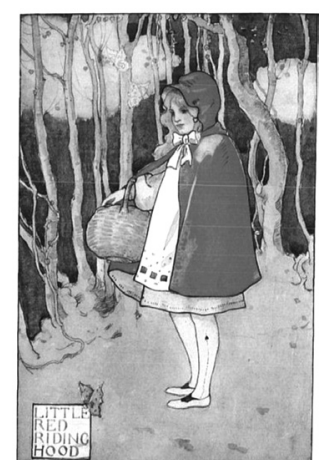

\section{Las otras miradas}

De este modo, la última sección de este estudio se ocupa de "las otras ilustraciones" del cuento de Caperucita Roja, en el sentido de que representan otros personajes u otros momentos narrativos, incluso otras interpretaciones del cuento, para fines publicitarios, por ejemplo.

La primera escena nos permite retornar, obligatoriamente, al siglo XIX y a los magistrales grabados de Doré, con la tercera y última de las tres planchas que dedicó al cuento. El artista escogió el preciso momento en que la bestia, erguida, salta sobre el lecho; la escena está repleta de detalles dramáticos. El primero que atrae la atención es la expresión aterrorizada de la abuela, cuyos anteojos, junto con el objeto que tenía en sus manos, salieron rodando hacia el suelo.

\section{Figura 21}

Gustave Doré, 1862

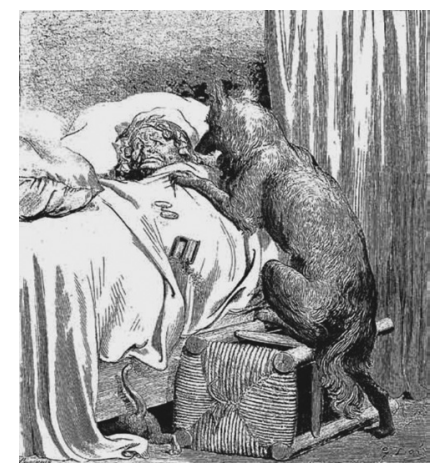


Además, el gato se precipita bajo el lecho, en tanto que el lobo, para alcanzar su objetivo, se alza sobre un taburete derribado. Toda esta acumulación de objetos desperdigados por el suelo da cuenta del ataque intempestivo del animal, el cual, como en la ilustración del encuentro en el bosque, se mantiene de espaldas a la mirada del espectador, quien debe intuir por la expresión de la víctima, la fuerza de su malignidad.

Resulta curioso que una edición holandesa de fines del siglo XIX parte, en gran medida, de la misma puesta en escena de Doré, como puede verse en la figura 22. Sin embargo, la ilustración se concentra en la lucha entre los dos personajes; no se trata de la sugerencia de lo que está por venir, como en Doré. En este caso, los contendientes están enfrascados en una desigual lucha a muerte. En este caso, obsérvese la corpulencia del lobo, el cual ya ha saltado al lecho y tiene asida a la abuela mientras la aproxima a sus fauces abiertas. La mujer, en un gesto de desesperación, levanta la mano como para pedir un socorro que no llegará.

Figura 22

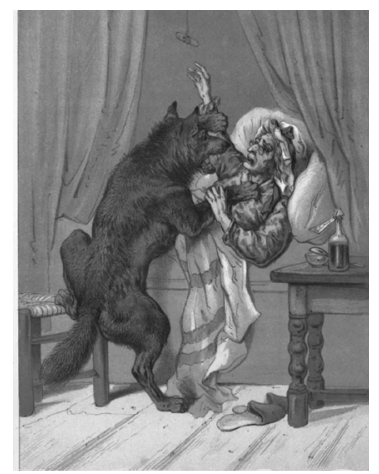

Edición holandesa, 1888
Figura 23

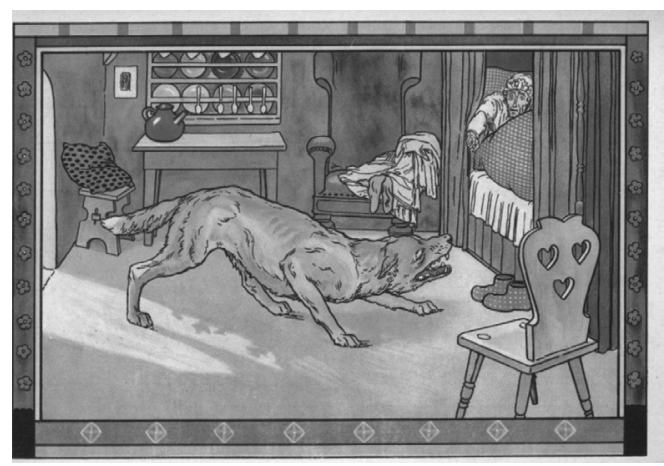

W. de Haan, 1925

La misma escena, ilustrada en 1925, se abstrae de mostrar el enfrentamiento entre los dos personajes y presenta el momento previo al ataque. El lobo ya ha entrado a la habitación y se dispone a saltar; la imagen empequeñecida de la abuela pone de manifiesto el terror que experimenta, en tanto que el animal es dibujado con rasgos de extrema ferocidad: las fauces abiertas, las garras crispadas y la mirada fija sobre su presa. Además, entre los detalles secundarios que generan interés se encuentra la multiplicidad de objetos representados en el interior de la habitación de la abuela: platos y cucharas de colores, una tetera, un cuadro colgando del muro, un taburete, una silla y una butaca, un cojín, ropa sobre la butaca y los zapatos de la abuela al pie del lecho; todo ello lleno de variados colores.

Otras ilustraciones de la época incluyen escenas que pertenecen, directamente, a la versión de los hermanos Grimm, pues representan el momento en que Caperucita y su abuela son rescatadas por el cazador. Una es la ilustración de Walter Crane que escenifica el rescate de la protagonista. El artista pertene- 
cía a un movimiento artístico (Arts and Crafts) que buscaba reivindicar el valor de la creatividad y la originalidad frente a la producción en serie, de tal forma que sus obras se caracterizan por el uso de líneas serpenteadas y asimétricas, difíciles de reproducir por millares.

La composición muestra al lobo muerto, desenmascarado. Los objetos de la abuela están en el suelo y Caperucita está fuertemente asida al abrigo del cazador, quien tiene su escopeta bajo el brazo izquierdo mientras que, con el derecho, señala hacia los despojos del animal. El rostro de Caperucita no es visible, solo su lenguaje corporal indica apremio por liberarse de la situación.

\section{Figura 24}

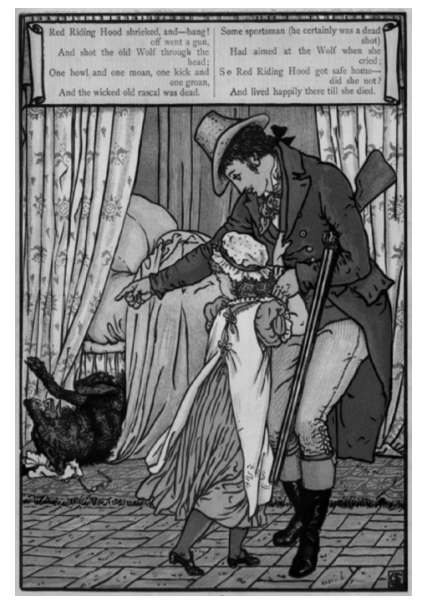

Walter Crane, finales del siglo XIX

La ilustración de la figura 25 aparece en una edición alemana llamada $E l$ Álbum Alemán (Das Deutsche Bilderbuch) de finales del siglo XIX. También, representa el momento del rescate por parte del cazador, pero la composición del cuadro varía notablemente con respecto a la figura anterior. Para empezar, se trata de Caperucita y de su abuela, quien aparece indemne después de haber sido devorada. A su lado, Caperucita se muestra solícita, sosteniendo lo que parece ser un frasco de sales.

Figura 25

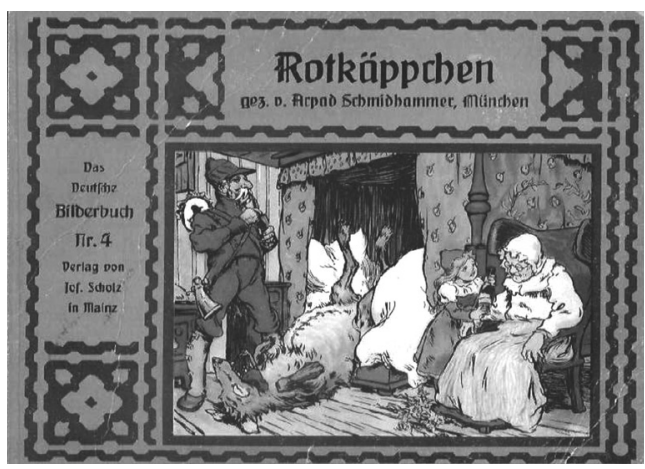

Arpad Schmidhammer, s.f. 
Así, las dos mujeres de la derecha contrastan fuertemente con el resto de la escena a la izquierda, donde destaca el cazador vestido de verde y con apariencia de montañés: grandes bigotes, sombrero calado hasta las orejas y cuerno colgando al cinto. A sus pies yace el lobo despatarrado, con las fauces abiertas y la lengua pendiente horriblemente. Además, una espantosa herida le atraviesa el vientre de arriba a abajo, como clara referencia a la liberación de la abuela. La estampa es una representación del final feliz del cuento de Grimm, las mujeres son rescatadas, el cazador es el héroe y el malvado recibe su merecido.

Cabe mencionar que la imagen más impactante de este estudio retoma la misma escena del rescate de Caperucita y la muerte del lobo, pero en este caso la manifiesta expresión de la violencia resulta perturbadora. Pertenece a una obra editada en San Petersburgo a principios del siglo XX e ilustrada por artistas holandeses. Actualmente, se encuentra en la Biblioteca Nacional de los Países Bajos.

En esta, el lobo es decapitado (con profusión de sangre que desborda la ilustración) por el cazador, quien no utiliza su escopeta, sino un hacha. Además, es evidente que el animal tiene a la abuela en su interior, lo que explica la expresión suplicante de Caperucita y el semblante furioso del cazador/leñador. Igualmente, puede verse que la vestimenta de ambos corresponde con la de la zona rural, así como la fisionomía corresponde con la de campesinos, quienes viven en cabañas rústicas, como la que se ve en la figura y que reciben el nombre de izbas.

Figura 26

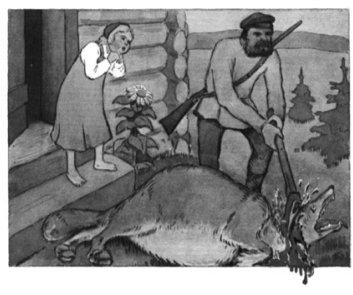

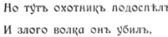

и бабушиу освоболи.
Figura 27

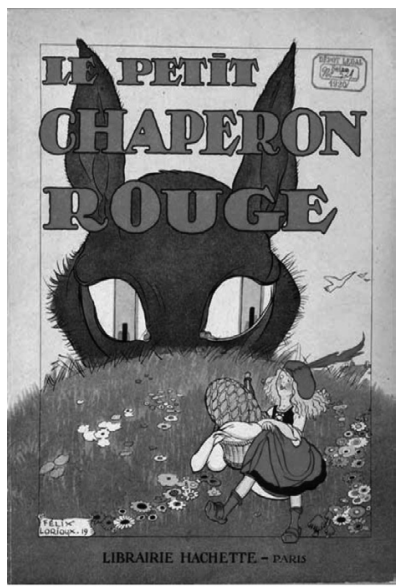

Félix Lorioux, 1920

Christiaan Hendrik Jacob van Niftrik, inicios del siglo XX

Por otra parte, la edición de Petit Chaperon Rouge de la Librairie Hachette en 1920 está ilustrada por Félix Lorioux y provee ilustraciones con aires nuevos para el cuento de Perrault. Se trata de una edición para niños, por lo que el aspecto visual se ocupa de mostrar imágenes muy atractivas. La novedad estriba en la composición de las ilustraciones, la cual permite la coexistencia 
de diferentes planos, tal y como sucede en el diseño de la cubierta. De ahí que el efecto sobrecogedor queda reforzado por la presencia del lobo como poder omnisciente al acecho, mientras Caperucita corre despreocupada por el prado.

Esta ilustración de Lorioux renueva completamente todo lo que se había hecho hasta el momento; no es necesario incluir otro detalle que indique la peligrosidad del lobo, basta con haberle otorgado el poder sugerido por su tamaño y su mirada fija sobre alguien que no sabe que está siendo observada.

\section{Figura 28}

Félix Lorioux, 1920

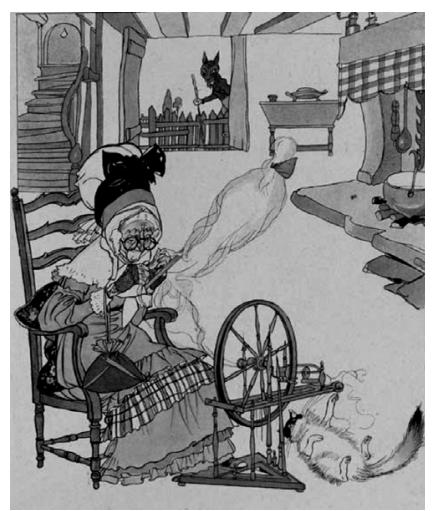

Otra de las ilustraciones (figura 28) de la misma publicación resulta también innovadora porque refleja elementos que habían sido ignorados hasta entonces, con lo que la iconografía de Caperucita se ve definitivamente renovada. La imagen presenta a la abuela sentada hilando en la rueca, pasiblemente, mientras el gato juega con el hilo y hay algo cocinándose en el fuego de la chimenea. Puede verse la casa en perspectiva, el espectador forma parte de la escena y es el único conciente del peligro que amenaza a la abuela en ese preciso instante, pero no podrá advertírselo.

Figura 29

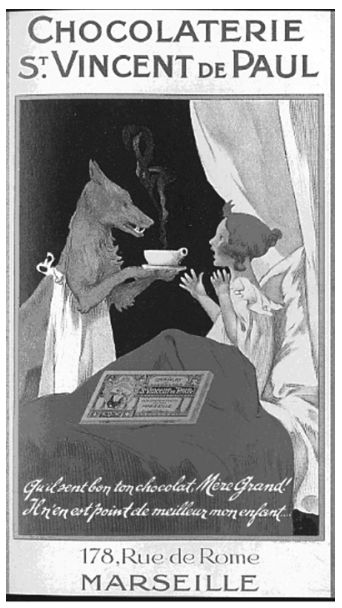

Publicidad de la chocolatería Saint-Vincentde-Paul, 1925 
Posteriormente, en 1925 y 1939 pueden encontrarse dos nuevas ilustraciones, cuya interpretación del cuento dista de la clásica imagen. De nuevo, la iconografía es modificada. Esto obedece a los fines para los cuales fueron creadas las imágenes; nos referimos no solamente a la ilustración de libros de cuentos, sino también a los afiches publicitarios inspirados en los personajes del lobo y Caperucita.

En primera instancia, la imagen resulta simpática para el espectador, los roles están intercambiados y el lobo tiene carácter humano. Quien está en el lecho no es la abuela, sino Caperucita, el detalle rojo se encuentra en las sábanas, pues ambos personajes visten de blanco para crear un efecto de paz y armonía. La sensación de divertimiento en el espectador se acrecienta al leer las viñetas al pie de página: "iQué delicioso huele el chocolate, abuela!" "No existe uno mejor, mi pequeña."

El afiche de 1939 no es sino una muestra al mejor estilo "Art Déco" de la primera mitad del siglo XX, como se infiere por la geometrización de las formas. La fisionomía de Caperucita carece de vivacidad, en tanto que la del lobo permanece ambigua, como también imprecisa es la cercanía de los personajes, es imposible saber si se trata de un encuentro anodino o si es algo diferente. A excepción obvia de la capa roja, los colores usados son completamente neutros y no puede identificarse el entorno de los personajes. Esta representación reducida a lo esencial de los personajes es acompañada por la clásica frase inicial de los cuentos; es este enunciado el que completa el significado de la composición, legitimando así su carácter representativo.

Figura 30

Póster norteamericano, 1939

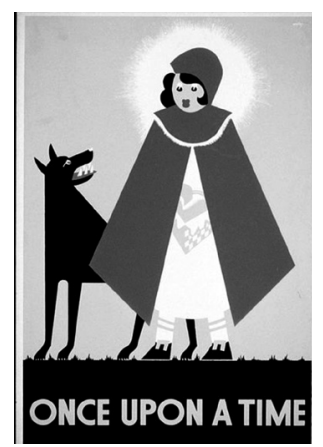

Sin embargo, un observador avezado podría incluso atribuir connotaciones sexuales a la posición de las figuras geométricas y la disposición de la niña y el animal, pues puede establecerse cierto parecido entre la imagen de Caperucita y la representación de los genitales femeninos, así como también puede resaltarse el hecho de que una de las patas del animal sale de en medio de las piernas de la niña. De tal forma, la candidez de la imagen queda severamente cuestionada.

Finalmente, el orden cronológico de las ilustraciones nos remite a una interpretación de 1965 que tiene el mérito de representar de forma inédita el cuento de Perrault. La edición de Le Petit Chaperon rouge de Maegth, ilustrada por Warja Lavater, tiene la particularidad de que no posee ningún texto aparte de 
la leyenda. El personaje principal, los personajes secundarios y el entorno están simbolizados por puntos de colores en un proceso tendiente a la abstracción. El libro propone una lectura continua, pues está conformado por una única página desplegable de 4.74 metros, lo cual permite abarcar toda la intriga con una sola mirada. La adaptación tuvo una calurosa acogida y ha seguido reimprimiéndose hasta la fecha en la editorial Seuil de París.

\section{Figura 31}

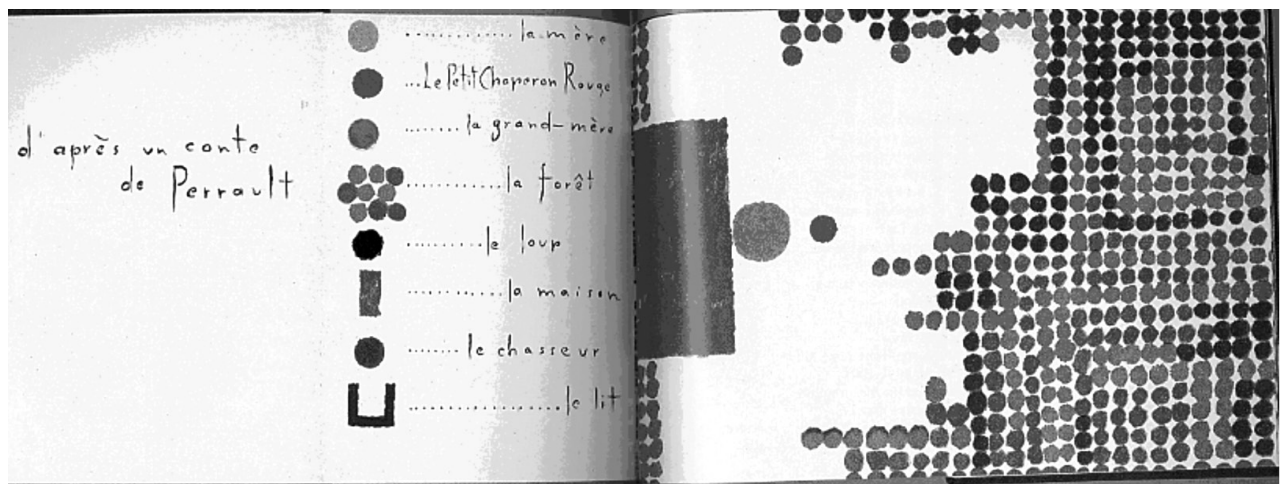

Warja Lavater, 1965

\section{Conclusiones}

El análisis de las diferentes ilustraciones del cuento Caperucita roja, desde la edición manuscrita de 1695, hasta la segunda mitad del siglo XX, nos permite proponer una serie de afirmaciones que han podido verificarse. Primera, la fascinación conseguida por Perrault con su primera versión escrita del cuento popular no ha dejado de acrecentarse, se ha mantenido viva durante más de tres siglos y, aún hoy, en todo el mundo las casas editoriales siguen lanzando al mercado versiones ilustradas de los cuentos de Perrault o de Grimm, o bien el cuento individual. Con ello, se cumple la afirmación de que como libro álbum es un género en permanente construcción.

Segundo, a lo largo de los diferentes siglos, los mejores ilustradores sucumbieron a la magia de la historia entre la niña y el lobo. Basta con mirar muestras iconográficas de Gustave Doré, Carl Offterdinger, Félix Lourioux o George Frederic Watts, por ejmeplo, para darse cuenta de que en medio de la vastedad de sus obras, Caperucita encuentra un lugar privilegiado.

Tercero, aunque se trata de una de las pocas heroínas de cuento que se resiste a crecer, permanece en una infancia eterna, y la mirada de los artistas ha percibido esa infancia de maneras muy distintas, que van desde resaltar el candor más puro, hasta sugerir el despertar sexual de la mujer.

Cuarto, de la misma forma, el personaje del lobo ha sido representado de las formas más disímiles y hasta contradictorias. En virtud de lo anterior, se puede 
afirmar que si bien es cierto que los caracteres están muy bien delimitados en la historia, no sucedió lo mismo con la iconografía de los personajes.

Quinto, por otra parte, los intereses de los artistas ilustradores sufrieron una gradual ampliación, a medida que se multiplicaban las posibilidades editoriales; así, nuevos personajes y nuevas escenas fueron enriqueciendo la iconografía del cuento.

Sexto y último, el único rasgo permanente a través de las épocas y las diversas interpretaciones es el color rojo que, como parte de sus vestimentas, lleva la protagonista: a veces como capa y, otras, como simple sombrero. Cuando se consideran las implicaciones simbólicas que se han atribuido a este color, el lector no puede menos que interrogarse acerca de la autenticidad de la inocencia infantil del personaje.

Definida justamente por su vestimenta, Caperucita Roja es metonimia: sin rasgos predeterminados ha hecho las delicias de la imaginación de los ilustradores, quienes permanecen libres de representarla según sus fantasías, pero conserva siempre el rasgo definitivo, la parte que define al todo como personaje: el rojo. Este detalle toma relevancia si se considera el hecho de que es el color cálido por excelencia, asociado al fuego, a la pasión y a la sangre, pero también al peligro y a la violencia.

De todo otro elemento que venga a la mente del lector se han podido identificar variaciones: en las fisionomías, en las posturas, en la escenografía, en la puesta en escena y en los elementos complementarios. Sin embargo, no puede obviarse el encanto permanente de la historia y el deseo, aunque suene próximo al sadismo, de querer acompañar a la niña despreocupada quien pagó tan cara su imprudencia.

\section{Notas}

1 En los cuentos que nuestros ancestros inventaron para sus hijos, siempre tuvieron el mayor cuidado de que contaran con una moraleja admirable e instructiva. En todos ellos la virtud es recompensada y el vicio castigado. Todos tienden a señalar la ventaja de ser honesto, paciente, trabajador, obediente, precavido y el mal que adviene a todo el que no lo sea. Traducción nuestra.

2 Como serie de pinturas, las ilustraciones pueden ser consideradas desde dos perspectivas: se puede estudiar la secuencia de imágenes en una sola edición [...]; o se puede investigar las transformaciones iconográficas en las versiones sucesivas del mismo episodio. [...] Este último acercamiento revela los cambios en la lectura y en la esperada recepción del texto. De hecho, el método ideal es una combinación de ambos, usando los ejes sintagmático y paradigmático para determinar los arquetipos ilustrativos y sus posteriores derivaciones en estereotipos.

3 Digo lobo, porque todos los lobos no son de la misma especie, los hay de carácter complaciente sin ruido, sin hiel y sin rabia 
¡Pero cuidado! Quien no sabe que esos lobos dulcificados

De todos los lobos son los más peligrosos.

\section{Bibliografía}

Andricain, Sergio y Antonio Orlando Rodríguez. Puertas a la lectura. San José, Costa Rica: Ministerio de Cultura, Juventud y Deportes, 1994.

Bajour, Cecilia y Marcela Carranza. "Relaciones entre imagen y texto en los libros ilustrados infantiles". Modos de construir sentidos en el libro álbum. Imaginaria $\mathrm{n}^{\circ}$ 226. Buenos Aires.

Barthes, Roland. "Introducción al análisis estructural de los relatos." Comunicaciones $\mathrm{n}^{0}$ 8. ( $2^{\mathrm{a}}$ ed.). Trad. Beatriz Dorriots. Buenos Aires: Editorial Tiempo Contemporáneo.

Bremond, Claude. "La lógica de los posibles narrativos." Comunicaciones $\mathrm{n}^{\mathrm{o}}$ 8. $\left(2^{\mathrm{a}}\right.$ ed.). Trad. Beatriz Dorriots. Buenos Aires: Editorial Tiempo Contemporáneo.

Hanán Diaz, Fanuel. Leer y mirar el libro álbum, ¿un género en construcción? Bogotá : Editorial Norma, 2007.

Jacques, Georges. " Du texte à l'illustration. Ambiguïtés féminines dans les Contes de la mère l'Oye ". Carnets des échanges interdépartementaux. Université Louvain-la-Neuve, 2001.

Le Men, Ségolène. " Mother Goose Illustrated : From Perrault to Doré”. Poetics Today $\mathrm{n}^{0}$ 13. The Porter Institute for Poetics and Semiotics. Tel Aviv University, 1992.

Lessing, Gotthold Ephraim. Laocoonte. Trad. Amalia Roggio. México: UNAM, 1960.

Marin, Louis. " Préface-image: Le frontispice des contes de Perrault ». Europe, novembre- décembre. París.

Perrault, Charles. Contes de ma mère l'Oye. Paris: Gallimard. Collection Folio, 2000.

Propp, Vladimir. Morfología del cuento. Ed. Rodolfo Alonso . Buenos Aires, 1972.

\section{Fuentes de Internet:}

http://www.europe-revue.info/

http://dore.artpassions.net/

http://www.materialesdelengua.org/LITERATURA/TEXTOS_LITERARIOS/

CUENTOS/contar/clasificacion.htm

http://www.ciudadseva.com/textos/teoria/hist/anonimo.htm

Biblioteca Nacional de Francia

http://expositions.bnf.fr/rouge/gp/01.htm

Biblioteca Nacional de los Países Bajos

http://www.kb.nl/uitgelicht/kinderboeken/roodkapje/roodkapje-ill.html 
